\title{
How can plant genetic engineering contribute to cost-effective fish vaccine development for promoting sustainable aquaculture?
}

\author{
Jihong Liu Clarke • Mohammad Tahir Waheed • \\ Andreas G. Lössl • Inger Martinussen • \\ Henry Daniell
}

Received: 4 February 2013/Accepted: 23 May 2013/Published online: 1 June 2013

(c) The Author(s) 2013. This article is published with open access at Springerlink.com

\begin{abstract}
Aquaculture, the fastest growing food-producing sector, now accounts for nearly $50 \%$ of the world's food fish (FAO in The state of world fisheries and aquaculture. FAO, Rome, 2010). The global aquaculture production of food fish reached 62.7 million tonnes in 2011 and is continuously increasing with an estimated production of food fish of 66.5 million tonnes in 2012 (a $9.4 \%$ increase in 1 year, FAO, www.fao.org/fishery/topic/16140). Aquaculture is not only important for sustainable proteinbased food fish production but also for the aquaculture industry and economy worldwide. Disease prevention is the key issue to maintain a sustainable development of aquaculture. Widespread use of antibiotics in aquaculture has led to the development of antibiotic-resistant bacteria and the accumulation of antibiotics in the environment, resulting in water and soil pollution. Thus, vaccination is the most effective and environmentally-friendly approach to combat diseases in aquaculture to manage fish health. Furthermore, when compared to $>760$ vaccines against
\end{abstract}

J. L. Clarke $(\bowtie) \cdot$ I. Martinussen

Bioforsk, Norwegian Institute for Agricultural and

Environmental Research, Ås, Norway

e-mail: jihong.liu-clarke@bioforsk.no

\section{T. Waheed}

Department of Biochemistry, Faculty of Biological Sciences, Quaid-i-Azam University, Islamabad 45320, Pakistan

A. G. Lössl

Department of Crop Sciences, University of Natural Resources and Applied Life Sciences, Vienna, Austria

H. Daniell

Departments of Biochemistry and Pathology, University of Pennsylvania School of Dental Medicine, 240 South 40th St, 547 Levy Building, Philadelphia, PA 19104, USA human diseases, there are only about 30 fish vaccines commercially available, suggesting the urgent need for development and cost-effective production of fish vaccines for managing fish health, especially in the fast growing fish farming in Asia where profit is minimal and therefore given high priority. Plant genetic engineering has made significant contributions to production of biotech crops for food, feed, valuable recombinant proteins etc. in the past three decades. The use of plants for vaccine production offers several advantages such as low cost, safety and easy scaling up. To date a large number of plant-derived vaccines, antibodies and therapeutic proteins have been produced for human health, of which a few have been made commercially available. However, the development of animal vaccines in plants, especially fish vaccines by genetic engineering, has not yet been addressed. Therefore, there is a need to exploit plant biotechnology for cost effective fish vaccine development in plants, in particular, edible crops for oral fish vaccines. This review provides insight into (1) the current status of fish vaccine and vaccination in aquaculture, (2) plant biotechnology and edible crops for fish vaccines for oral administration, (3) regulatory constraints and (4) conclusions and future perspectives.

Keywords Aquaculture - Food security - Fish vaccine . Plant genetic engineering $\cdot$ Regulatory constraints

\section{Introduction}

Fish is an excellent animal protein source and contains a wide range of essential human nutrients. Up to $80 \%$ of the world's fish production is used for human consumption, indicating the important role of aquaculture for food security. Fisheries and aquaculture play also an important 
role in the livelihoods of millions of people worldwide from the small-scale inland fishermen who harvest fishes from lakes and rivers to the industrial scale fish farming. Thus, sustainable fish farming contributes considerably to food security (www.fao.org).

Aquaculture is the farming of aquatic organisms including fish, crustaceans, molluscs and aquatic plants. Fisheries and aquaculture make important contributions to the human population as protein sources. The global aquaculture production of food fish reached 62.7 million tonnes in 2011 and is continuously increasing with an estimated production of food fish of 66.5 million tonnes in 2012 (a $9.4 \%$ increase in 1 year, FAO, www.fao.org/ fishery/topic/16140). In the past five decades, the world fish supply has rapidly increased with an average growth rate of $3.2 \%$ per year and constitutes an important source of nutrition and animal protein for humans (FAO 2012; http://www.fao.org, Fig. 1). This is particularly the case in Asia, where approximately $90 \%$ of the total global aquaculture products comes from. Among the Asian countries, China alone produces ca. $70 \%$ of the world total volume of aquaculture products and has become the largest producer of farmed seafood in the world, with an increase of $490 \%$ since 1978 (Ellis 2009). It is estimated that in the next decade total production from both capture and aquaculture will exceed that of beef, pork or poultry. Due to higher demand for fish, world fisheries and aquaculture production are projected to reach about 172 million tonnes in 2021, of which aquaculture is projected to reach about 79 million tonnes, rising by $33 \%$ over the period 2012-2021 (FAO 2012, http://www.fao.org). This boom in aquaculture will help to achieve certain millennium development goals either directly (e.g. eradication of extreme poverty and hunger) or indirectly (e.g. substantial improvement in economies). However, aquaculture is as vulnerable to adverse impacts of disease and unfavourable environmental conditions as is farming of other animals. Disease outbreaks in recent years have affected Atlantic salmon, oyster and marine shrimp farming in several countries of the world, resulting in partial or sometimes total loss of production. In 2010, aquaculture in China suffered production losses of 1.7 million tonnes caused by natural disasters, diseases and pollution. Disease outbreaks virtually wiped out marine shrimp farming production in Mozambique in 2011 (FAO 2012). Fish diseases not only pose a threat to the aquaculture industry but also to human livelihood and health. Apart from zoonoses, use of certain chemicals and antibiotics for fish health also pose certain risks to the environment, human health and food security (for a review see Sapkota et al. 2008). Management of aquatic animal health is therefore an important issue for food security, to protect livelihoods of millions of people, the aquaculture industry and the environment.

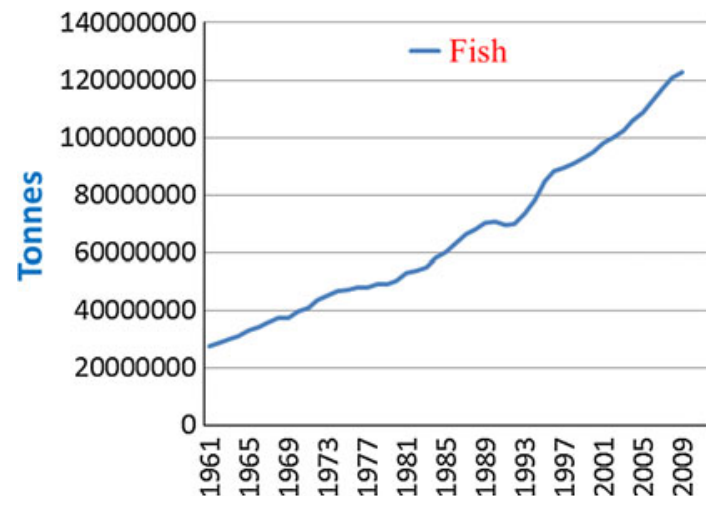

Fig. 1 Worldwide fish production in five decades. Data source (www.fao.org/fishery/aquaculture)

\section{History and current status of fish vaccines and vaccination approaches}

Compared with human vaccine history starting from the discovery of vaccination by Edward Jenner in 1796 leading to production of $>760$ vaccines for protecting human health, fish vaccine development has a very short history with roughly 40 years since the 1970s. It took over three decades from the first scientific report describing fish vaccination using an inactivated orally administrated Aeromonas salmonicida vaccine. The first licensed fish vaccine was made commercially available in 1976 (Evelyn 1997). The first fish vaccine was produced from killed Yersinia ruckeri, and used to protect fishes against enteric redmouth (ERM) by oral administration. Soon after the release of ERM oral fish vaccine, a new vaccine for Vibrio anguillarum became available in the USA with vaccination via immersion. These were followed with the release of Furunculosis vaccines in Europe in the 1980s. To date, there are no more than 30 commercial vaccines for the prevention of a wide range of fish diseases, with a few more under development (Smith 2008). The economic, environmental and animal welfare benefits have been recognised as a result of the widespread use of vaccines in the aquaculture industry. The potential from vaccines for lower mortality, improved growth efficiency and higher yields is now a critical factor in disease management programmes in aquaculture. To date, commercially used fish vaccines are mainly: killed vaccines such as inactivated virus or bacterial antigens, subunit vaccines and recombinant vaccines with humoral (antibody) responses, or live, attenuated and DNA vaccines for cytotoxic $\mathrm{T}$ cell response (Plant and LaPatra 2011, http://www.pharmaq.no).

At present, three main delivery approaches are used for fish vaccination: (1) injection vaccination, (2) oral vaccination, and (3) immersion vaccination (including bath and spray vaccination). The advantages and drawbacks of each vaccination method are summarized in Table 1 . 
Table 1 Fish vaccination methods and their advantages and drawbacks [adapted from Plant and LaPatra (2011) and http://www.pharmaq.no]

\begin{tabular}{|c|c|c|}
\hline $\begin{array}{l}\text { Vaccination } \\
\text { method }\end{array}$ & Advantages & Drawbacks \\
\hline $\begin{array}{l}\text { Injection } \\
\text { Intraperitoneal } \\
\text { (adjuvanted or } \\
\text { not) } \\
\text { Intramuscular } \\
\text { (DNA) }\end{array}$ & $\begin{array}{l}\text { Most common method of vaccine delivery } \\
\text { in fish } \\
\text { Effective in generating both humoral } \\
\text { (antibody) and cellular cytotoxic } \\
\text { response } \\
\text { Protection is of long duration }\end{array}$ & $\begin{array}{l}\text { Not feasible for fishes under } 20 \mathrm{~g} \\
\text { Stressful for the fish due to handling and } \\
\text { anesthetizing } \\
\text { Labour intensive } \\
\text { Expensive (high labour costs or } \\
\text { expensive injection machine) }\end{array}$ \\
\hline $\begin{array}{l}\text { Oral } \\
\text { Micro- } \\
\text { encapsulation } \\
\text { Bio-encapsulation }\end{array}$ & $\begin{array}{l}\text { Ideal delivery method via feed } \\
\text { Easiest, no technical skill required } \\
\text { No handling stress for the fish } \\
\text { Protection from the digestive system } \\
\text { No additional labour cost } \\
\text { No investment on instrument required } \\
\text { Feasible for mass vaccination of all sizes } \\
\text { of fishes }\end{array}$ & $\begin{array}{l}\text { Large amount of antigen needed } \\
\text { Poor and short-term protection (except } \\
\text { for } Y \text {. ruckeri and } V \text {. anguillarum). } \\
\text { Gastric degradation can affect } \\
\text { protective antigen }\end{array}$ \\
\hline $\begin{array}{l}\text { Immersion by } \\
\text { Bath } \\
\text { Spray } \\
\text { Dip }\end{array}$ & $\begin{array}{l}\text { Simple and suitable for mass vaccination } \\
\text { Less stress for the fish than injection } \\
\text { Lower labour costs } \\
\text { Less risk to vaccination team }\end{array}$ & $\begin{array}{l}\text { Not suitable for all farmed fishes } \\
\text { Stressful for the fish because of netting } \\
\text { and transportation prior to spray } \\
\text { vaccination } \\
\text { Large amount of vaccine required in the } \\
\text { case of the bath method } \\
\text { Lower level of protection and duration } \\
\text { of immunity }\end{array}$ \\
\hline
\end{tabular}

Given that none of the vaccination approaches are universal, choice of vaccination method will be largely determined by the type and size of the fish, protection required, pathogen's nature, type of immune reaction required and the vaccine's nature (single or multivalent), as well as the cost which is essential for fish industry and small fish farmers in the developing countries. New fish vaccine development and the production of fish vaccines require that vaccines must be effective and suitable for large-scale production at low cost, making the vaccines available and affordable to the aquaculture fish industry and small fish farmers in the developing countries.

Facing economic pressure in the aquaculture industry, intensive fish farming has increased the spread of diseases and parasites. To manage the problem, a large amount of antibiotics are applied in aquaculture with the hope of enhancing production and improving the socioeconomic profile of the fish farmers in the developing countries.

The presence of antibiotic compounds in the aquatic environment has resulted in environmental pollution, especially water pollution. It leads also to the development of antibiotic-resistant bacteria making bacterial disease control in aquaculture a challenging task. Increased mortality of Penaeus monodon larvae due to antibiotic-resistant Vibrio harveyi infection has been reported (Karunasagar et al. 1994). Furthermore, infectious diseases in aquaculture are caused not only by bacteria but also viruses, fungi and parasites. Thus, vaccination is the most effective way to protect fishes and to manage aquaculture in an environmentally friendly manner. Application of plant biotechnological tools for fish vaccine development is of importance for aquaculture as the fish vaccines have to be produced at a low cost and for easy scaling up, making them accessible and affordable for not only the aquaculture industry worldwide, but in particular for improvement of the conditions for small fish farmers in the developing countries.

\section{Exploitation of plant genetic engineering for low cost production of fish vaccines}

Fish have a functional immune system similar to mammals (innate and adaptive) and the advancement and experiences of plant biotechnology in vaccine development for humans and other mammals could be of importance for the development of fish vaccines. The use of plants for development and production of recombinant vaccines offers several advantages. Plant-based systems are more economical as plants can be grown on a larger scale than in other systems. Low cost is no doubt one of the most important issues in the future development of fish vaccines. Plants also possess the ability to carry out post-translational modifications similar to naturally occurring systems. The plant-based systems bypass the safety concerns inherent in live virus vaccines. 
To date, three main plant-based techniques have been used for the expression of a large number of vaccine antigens, monoclonal antibodies (mAbs) and other biopharmaceuticals in plants. These are (1) stable expression of transgenes in the nuclear genome of transgenic plants or cell culture, (2) stable expression of transgenes in the plastid genome of transplastomic plants by plastid genetic engineering and (3) transient expression of transgenes in plants. A number of reviews have covered all the three methodologies (Streatfield 2007; Daniell et al. 2009; Clarke and Daniell 2011; Lössl and Waheed 2011; Maliga and Bock 2011; Yusibov et al. 2011). Each system has its advantages and limitations and the method of choice is largely depending on what kind of fish vaccines are to be expressed, as briefly described in Table 2. To date, both food and non-food crops (especially tobacco plant) have been used for the development of a number of animal vaccines, such as a poultry vaccine against Newcastle disease (Hahn et al. 2007; Yang et al. 2007; Li et al. 2007; Gómez et al.2009; Van Eck and Keen 2009; Wu et al. 2009: for reviews see Floss et al. 2007 and He et al. 2008), rabies (Ashraf et al. 2005; Loza-Rubio et al. 2008; Roy et al. 2010; Loza-Rubio et al. 2012), Porcine reproductive and respiratory syndrome virus (PRRSV) and Porcine postweaning diarrhea in piglets (Chen and Liu 2011; Kolotilin et al. 2012). The vaccine against Newcastle disease was the first plant-made animal vaccine receiving regulatory approval from the US Department of Agriculture (USDA) Center for Veterinary Biologics in 2006 (www.thepoultry site.com/poultrynews/8949/usda-issues-license-for-plant-cellproducednewcastle-disease-vaccine-for-chickens; Joensuu et al. 2008).

Moreover, studies on plant-based animal vaccines for protecting mink, dogs, and cats are reported (Dalsgaard et al. 1997; Molina et al. 2004). Molina et al. (2004, 2005) demonstrated high-level expression of a tobacco chloroplast-derived vaccine based on a B cell epitope from canine parvovirus and the induction of neutralizing antibodies. Three recent reviews by Floss et al. (2007), Joensuu et al. (2008) and Rybicki (2010) have provided an overview of production of veterinary vaccines in plants. However, plants as expression systems for production of fish vaccines are lagging behind compared with the plant-made veterinary vaccines for non-aquatic (land-based) animals. Based on the special advantages of oral vaccination in aquaculture, Companjen et al. (2005) successfully expressed the non-toxic part of the $E$. coli heat-labile enterotoxin LTB fused with a viral peptide or GFP in potato tuber for oral immunization and induction of specific humoral immune response in carp upon feed-mediated administration. This study demonstrated the feasibility of producing fish vaccines for oral vaccination in an edible crop and the technology shall be explored further. To boost an efficient delivery of plant-made oral fish vaccine to immune-competent cells in the gut mucosa, a carrier molecule i.e. LTB in the study was fused to the oral vaccine antigens to stimulate the uptake and immune response upon feedmediated oral immunization.. Another attempt is our own ongoing research in production of a fish vaccine in tobacco chloroplasts against viral nervous necrosis (VNN) caused by Nodavirus (Clarke et al. ongoing research). VNN affects farmed fish such as turbot, Atlantic halibut and Atlantic cod, as well as wild fish (Grotmol et al. 1995, 1997; Munday et al. 2002; Sommerset et al. 2005). The risk of VNN spreading from escapes of farmed fish to wild indicates the significance of the development of a cost effective and safe vaccine against VNN infection. The economic importance of such a vaccine for farmed fish is self-evident. In this study, transplastomic tobacco lines expressing RNA2 as the antigen candidate were produced and are currently subject to various molecular analyses (Clarke et al. unpublished results).

\section{Engineering edible crops for the development of fish vaccines for oral immunization}

Edible crops are ideal green factories for the production of therapeutic proteins and vaccines for oral immunization. In aquaculture, among the current fish vaccination methods shown in Table 1, a fish vaccine produced in an edible crop (or microalgae) for oral immunization is undoubtedly advantageous because oral vaccination of fish is an easy, labour-saving and stress free method which is suitable for all fishes independent of the fish size.

Despite the advantages and potentials of plant vaccine production systems for animal health including aquatic animals, there are only a few studies reporting the veterinary vaccine antigens expressed in edible crops, only one case for fish vaccine produced in potato for oral delivery via feed suggesting strongly that research effort is needed to develop and advance the research field in the future for effective management of fish health by cost effective plantmade oral fish vaccines. Successful management of fish health will directly contribute to sustainable food fish production in the future. To date, lettuce and potato tubers have been used for the development of plant-based animal vaccines (Companjen et al. 2005; Gómez et al. 2008; Matsui et al. 2009). So far, there is no report describing fish vaccine antigens expressed in edible crops by plastid genome engineering, despite the technology for plastid engineering of edible crops such as lettuce, tomato, potato, cabbage etc. having been developed and used to express a number of foreign proteins (Kanamoto et al. 2006; Ruf et al. 2001; Ruhlman et al. 2007, 2010; Daniell et al. 2009; Cardi et al. 2010; Clarke and Daniell 2011; 
Table 2 Plant expression systems and their future application in fish vaccine development

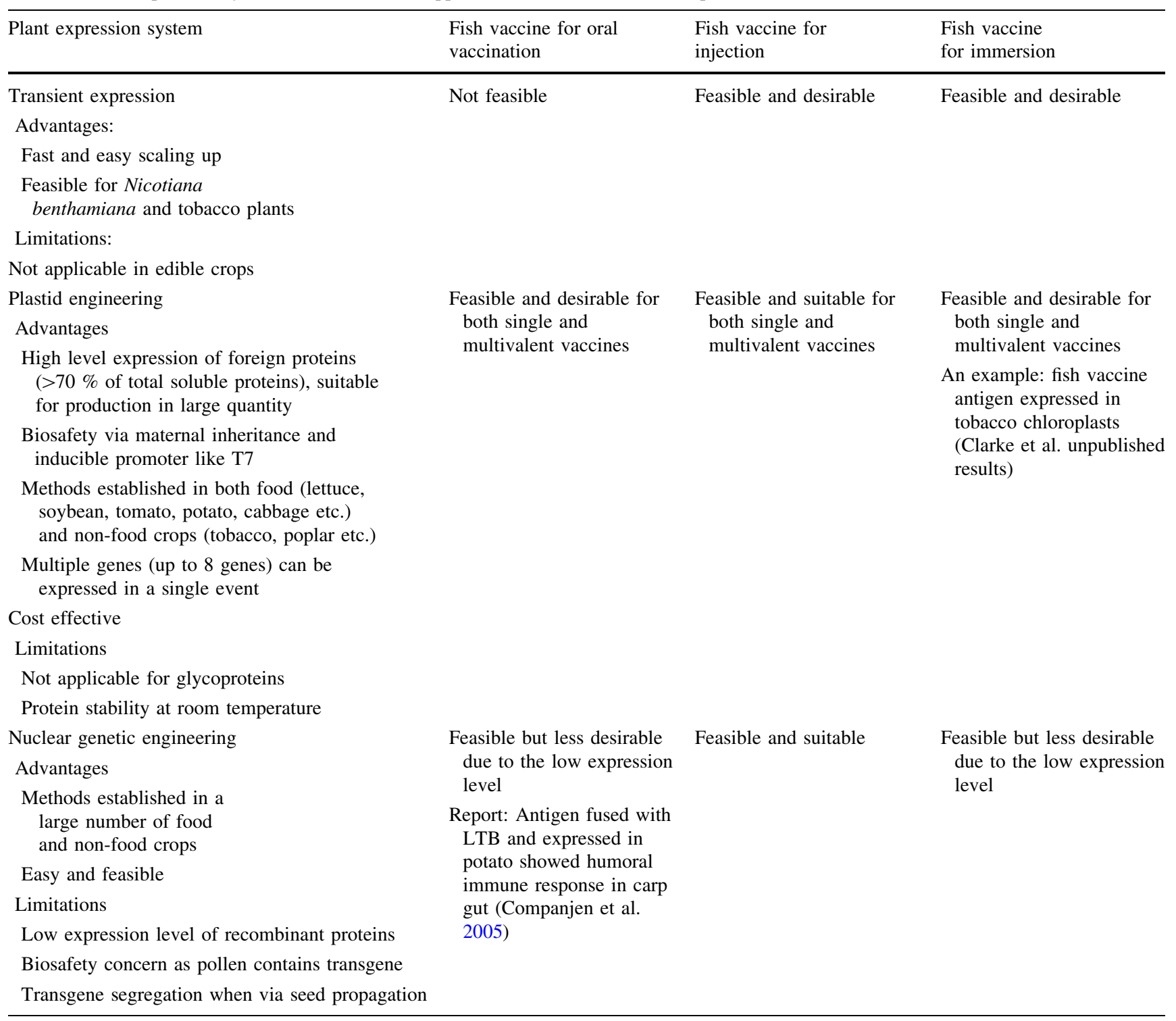

Davoodi-Semiromi et al. 2010; Kanagaraj et al. 2011; Boyhan and Daniell 2010; Lakshmi et al. 2013). Based on the experience from human vaccines produced in edible crops, the development of fish vaccines in edible crops for oral vaccination will be a reality in the future.

\section{Regulatory constraints}

It was 30 years ago when the first genetically modified (GM) plant was produced by using Agrobacterium tumefaciensmediated genetic transformation (for historical perspective see Bevan et al. 1983; Fraley et al. 1983; Herrera-Estrella et al. 1983 and review by Vasil 2008). Thirteen years later, the first GM crop was commercialized in 1996 (http://www.isaaa.org). Since then, there has been a fast development with first, second and third generations of GM plants produced worldwide. Despite the encouraging news that the global status of commercialized biotech crops has reached 170.3 million hectares globally in 2012 (http://www.isaaa.org), at an annual growth rate of $6 \%$, up 10.3 million from 160 million hectares in 2011 and with significant benefits for farmers, the regulatory constraints are a well-known hurdle for commercialization of biotech crops in many countries, especially in Europe. Molecular farming using plants or plant cell lines as a green factory to produce vaccines and biopharmaceuticals has also made considerable progress with commercially released plantmade therapeutic proteins, and a number of vaccines and therapeutic proteins are undergoing clinical trials or are in 
the pipeline to be approved (Yusibov et al. 2011; http://www.genengnews.com/gen-news-highlights/); however, it has encountered the same regulatory constraints as other GM crops. Under the current regulatory requirements, it's estimated that it takes on average 7-10 million euros to approve a GM crop for cultivation (Paul et al. 2011).

Current USDA-APHIS regulatory requirements are based on the use of plant pathogens (Agrobacterium) for transformation or use of plant pathogenic sequences (Agrobacterium genome sequence or plant viral genome sequence, especially the CaMV promoter). So, in order to minimize regulatory costs, one could use the chloroplast transformation approach for molecular pharming, which doesn't use any plant pathogenic sequences. This approach should significantly minimize the cost of regulatory approval for field studies. Indeed, plant-made pharmaceuticals engineered via the chloroplast genome have been tested in the field several years ago (Arlen et al. 2007). One among the most important regulatory hurdles for molecular pharming is transgene containment. Early plant-made vaccine companies were shut down by USDA-APHIS for contamination of food/feed grains by corn seeds expressing human therapeutic proteins (e.g. Prodigene). Such regulatory challenges could therefore be avoided by not expressing vaccines in seeds. For example, expressing vaccine antigens in leaves facilitates their harvest before appearance of any reproductive structures, thereby avoiding contamination via pollen or seeds (Daniell et al. 2009). In addition, expressing vaccine antigens via the chloroplast genome facilitates maternal inheritance of transgenes and minimizes or eliminates out-cross via pollen (Daniell 2007; Daniell et al. 1998).

Another important cost in regulatory approval is the need for release into the environment, requiring large acreage of field studies in different geographical locations. However, for molecular pharming using the chloroplast transformation approach, high levels of expression result in minimal acreage. For example, one acre of cultivation could produce up to 360 million doses of vaccines (Koya et al. 2005; Watson et al. 2004). Thus, the production could be contained within the greenhouse, eliminating the need for field release.

So far, none of the plant-made vaccines has been approved for oral delivery, an essential requirement for low cost fish vaccine. Bioencapsulation protects vaccine antigens expressed within plant cells, and they are released in the gut by the action of microbes colonizing the gut ( $\mathrm{Li}$ maye et al. 2006; Kwon et al. 2013a, b; Arlen et al. 2008; Davoodi-Semiromi et al. 2010). However, neither the transient viral expression system that infects plant cells nor low level expression of stable nuclear expression is ideal for oral delivery of vaccines. However, several oral vaccines expressed via the chloroplast genome have been shown to be effective against pathogen or toxin challenge (Davoodi-Semiromi et al. 2010; Arlen et al. 2008) or immune disorders (Ruhlman et al. 2007; Verma et al. 2010). In addition, regulatory agencies require demonstration of long-term stability of vaccine at room temperature. Such stability has been shown by storage of lyophilized leaf materials for several months or years expressing human therapeutic proteins (Kwon et al. 2013a, b), vaccine antigens or autoantigens (Lakshmi et al. 2013, Kwon et al. 2013a, b). Moreover, the process of lyophilization eliminates microbes that colonize plants, an important regulatory requirement (Kwon et al. 2013a). In addition, the concentration of vaccine antigens is increased 15-25 fold, significantly reducing the amount of plant materials required for effective vaccination (Kwon et al. 2013a). The aforementioned advantages make the lettuce chloroplast system ideal for oral vaccines and several human therapeutic proteins have been expressed at high levels in lettuce chloroplasts (Davoodi-Semiromi et al. 2010; Kanagaraj et al., 2011; Boyhan and Daniell 2010; Lakshmi et al. 2013; Ruhlman et al. 2007, 2010). Future studies should therefore focus on edible leaves rather than tobacco that has nicotine and other alkaloids, not permitted by any of the global regulatory agencies.

\section{Conclusions}

With the challenges of the growing world population, food security demand and unpredictable climate change, aquatic fish health and management have become a global concern which affects protein-based food security, the environment, and the aquaculture industry and millions of fish farmers in the developing countries. To use biotechnological tools to manipulate plants for low-cost and safe vaccine production for farmed fish is a research field which needs to be advanced and strengthened. This review has addressed these issues and provided an overview of the current situation in fish health management, the status of fish vaccine and vaccinations, as well as how to explore plant genetic engineering for the development and cost-effective production of fish vaccines. The utilization of plants for lowcost and large quantity production of fish vaccines with oral immunization by plant genetic engineering, especially plastid genetic engineering of edible crops, should be emphasized. Oral vaccination is of special importance for fishes weighing less than $20 \mathrm{~g}$. To promote an efficient delivery of plant-made oral fish vaccine to immune-competent cells in the gut mucosa, a carrier molecule such as LTB or CTB should be fused to the oral vaccine antigens to stimulate the uptake and immune response upon feedmediated oral immunization. Altogether, there is an urgent need for the research community to advance and implement plant genetic engineering of edible crops for production of fish vaccines for oral vaccination via feed. 
Acknowledgments We thank the Research Council of Norway for grant GLOBVAC NFR 192510, Bioforsk for providing core funding for "Plants for non-food application" to Dr Jihong Liu Clarke as well as the Bioforsk SIS program to Dr Inger Martinussen and the NIH R01 HL 109442 and NIH R01 HL 107904, Bill and Melinda Gates Foundation Global Health Grant OPP 1031406 and the Juvenile Diabetes Research Foundation Grant 17-2011-286 to Dr. Henry Daniell. The authors thank Nicholas Clarke for his critical reading.

Open Access This article is distributed under the terms of the Creative Commons Attribution License which permits any use, distribution, and reproduction in any medium, provided the original author(s) and the source are credited.

\section{References}

Arlen PA, Falconer R, Cherukumilli S, Cole A, Cole AM, Oishi KK, Daniell H (2007) Field production and functional evaluation of chloroplast-derived interferon alpha $2 \mathrm{~b}$. Plant Biotechnol $\mathrm{J}$ 5:511-525

Arlen PA, Singleton M, Adamovicz JJ, Ding Y, Davoodi-Semiromi A, Daniell H (2008) Effective plague vaccination via oral delivery of plant cells expressing F1-V antigens in chloroplasts. Infect Immun 76:3640-3650

Ashraf S, Singh PK, Yadav DK, Shahnawaz M, Mishra S, Sawant SV, Tuli R (2005) High level expression of surface glycoprotein of rabies virus in tobacco leaves and its immunoprotective activity in mice. J Biotechnol 119:1-14

Bevan MW, Flavell RB, Chilton MD (1983) A chimeric antibioticresistance gene as a selectable marker for plant-cell transformation. Nature 304:184-187. doi:10.1038/304184a0

Boyhan D, Daniell H (2010) Low cost production of proinsulin in tobacco and lettuce chloroplasts for injectable or oral delivery of functional insulin and c-peptide. Plant Biotechnol J 9:585-598

Cardi T, Lenzi P, Maliga P (2010) Chloroplasts as expression platforms for plant-produced vaccines. Expert Rev Vaccines 9:893-911

Chen X, Liu J (2011) Generation and immunogenicity of transgenic potato expressing the GP5 protein of porcine reproductive and respiratory syndrome virus. J Virol Methods 173(1):153-158. doi:10.1016/j.jviromet.2011.02.001

Clarke JL, Daniell H (2011) Plastid biotechnology for crop production: present status and future perspectives. Plant Mol Biol 76:211-220

Companjen AR, Florack DE, Bastiaans JH, Matos CI, Bosch D, Rombout JH (2005) Development of a cost-effective oral vaccination method against viral disease in fish. Dev Biol (Basel) 121:143-150

Dalsgaard K, Uttenthal A, Jones TD, Xu F, Merryweather A, Hamilton WD, Langeveld JP, Boshuizen RS, Kamstrup S, Lomonossoff GP, Porta C, Vela C, Casal JI, Meloen RH, Rodgers PB (1997) Plant derived vaccine protects target animals against a viral disease. Nat Biotechnol 15:248-252

Daniell H (2007) Transgene containment via maternal inheritance. Proc Natl Acad Sci USA 104:6879-6881

Daniell H, Datta R, Varma S, Gray S, Lee SB (1998) Containment of herbicide resistance through genetic engineering of the chloroplast genome. Nat Biotech 16:345-348

Daniell H, Singh ND, Mason H, Streatfield SJ (2009) Plant-made vaccine antigens and biopharmaceuticals. Trends Plant Sci 14:669-679

Davoodi-Semiromi A, Schreiber M, Samson N, Verma D, Singh ND, Chakrabarti D, Daniell H (2010) Chloroplast-derived vaccine antigens confer dual immunity against cholera and malaria by oral or injectable delivery. Plant Biotechnol J 8:223-242

Ellis LJ (2009) Fishing murky waters: China's aquaculture challenges - upstream and downstream. Business forum China pp 1-2

Evelyn TPT (1997) A historical review of fish vaccinology. In: Gudding R, Lillehaug A, Midtlyng PJ, Brown F (eds) Developments in biological standardization: fish vaccinology, vol 90. International Association of Biological Standardization, Basel, pp 3-12

FAO (2010) The state of world fisheries and aquaculture. Rome, FAO

FAO (2012) The state of world fisheries and aquaculture. Rome, FAO. http://www.fao.org/docrep/016/i2727e/i2727e.pdf

Floss DM, Falkenburg D, Conrad U (2007) Production of vaccines and therapeutic antibodies for veterinary applications in transgenic plants: an overview. Trans Res 16:315-332

Fraley RT, Rogers SG, Horsch RB, Sanders PR, Flick JS, Adams SP, Bittner ML, Brand LA, Fink CL, Fry JS, Galluppi GR, Goldberg SB, Hoffmann NL, Woo SC (1983) Expression of bacterial genes in plant cells. Proc Natl Acad Sci USA 80:4803-4807

Gómez E, Chimeno Zoth S, Carrillo E, Estela Roux M, Berinstein (2008) Mucosal immunity induced by orally administered transgenic plants. Immunobiology 213:671-675

Gómez E, Chimeno Zoth S, Vázquez A, Rovere C, Berinstein A (2009) Expression of hemagglutinin-neuraminidase glycoprotein of newcastle disease virus in agroinfiltrated Nicotiana benthamiana plants. J Biotechnol 144:337-340

Grotmol S, Totland GK, Kvellestad A, Fjell K, Olsen AB (1995) Mass mortality of larval and juvenile hatchery-reared halibut (Hippoglossus hippoglossus L.) associated with the presence of virus-like particles in vacuolated lesions of the central nervous system and retina. Bull Eur Fish Pathol 15:176-180

Grotmol S, Totland GK, Thorud K, Hjeltnes BK (1997) Vacuolating encephalopathy and retinopathy associated with a nodavirus-like agent: a probable cause of mass mortality of cultured larval. Dis Aquat Org 29(8):5-97

Hahn BS, Jeon IS, Jung YJ, Kim JB, Parl JS, Ha SH, Kim KH, Kim HM, Yang JS, Kim YH (2007) Expression of hemagglutininneuraminidase protein of Newcastle disease virus in transgenic tobacco. Plant Biotechnol Rep 1:85-92

He Z, Du X, Yao W, Dai J (2008) Pharmaceutical proteins produced in plant bioreactor in recent years. Afr J Biotechnol 7:4917-4925

Herrera-Estrella L, De Block M, Messens E, Hernalsteens J-P, Van Montagu M, Schell J (1983) Chimeric genes as dominant selectable markers in plant-cells. EMBO J 2:987-995

Joensuu JJ, Niklander-Teeri V, Brandle JE (2008) Transgenic plants for animal health: plant-made vaccine antigens for animal infectious disease control. Phytochem Rev 7:553-577

Kanagaraj AP, Verma D, Daniell H (2011) Expression of dengue-3 premembrane and envelope polyprotein in lettuce chloroplasts. Plant Mol Biol 76:323-333

Kanamoto H, Yamashita A, Asao H, Okumura S, Takase H, Hattori M, Yokota A, Tomizawa K (2006) Efficient and stable transformation of Lactuca sativa L. cv. Cisco (lettuce) plastids. Transgenic Res 15:205-217

Karunasagar Pai R, Malathi GR, Karunasagar I (1994) Mass mortality of Penaeus monodon larvae due to antibiotic-resistant Vibrio harveyi infection. Aquaculture 128:203-209

Kolotilin I, Kaldis A, Devriendt B, Joensuu J, Cox E, Menassa R (2012) Production of a subunit vaccine candidate against porcine post-weaning diarrhea in high-biomass transplastomic tobacco. PloS One 7 doi:10.1371/journal.pone.0042405

Koya V, Moayeri M, Leppla SH, Daniell H (2005) Plant based vaccine: mice immunized with chloroplast- derived anthrax protective antigen survive anthrax lethal toxin challenge. Infect Immun 73:8266-8274

Kwon KC, Nityanandam R, New JS, Daniell H (2013a) Oral delivery of bioencapsulated exendin- 4 expressed in chloroplasts lowers 
blood glucose level in mice and stimulates insulin secretion in beta-TC6 cells. Plant Biotechnol J 11:77-86

Kwon KC, Verma D, Singh NK, Herzog RW, Daniell H (2013b) Oral delivery of human biopharmaceuticals, autoantigens and vaccine antigens bioencapsulated in plant cells. Adv Drug Deliv Rev. doi:10.1016/j.addr.2012.10.005

Lakshmi PS, Verma D, Yang X, Lloyd B, Daniell H (2013) Low cost tuberculosis vaccine antigens in capsules: expression in chloroplasts, bio-encapsulation, stability and functional evaluation in vitro. PLoS ONE 8:e54708

Li J, Chen M, Liu XW et al (2007) Transient expression of an active human interferon-beta in lettuce. Sci Hortic 112(3):258-265

Limaye V, Koya M, Samsam N, Daniell H (2006) Receptor mediated oral delivery of a bioencapsulated green fluorescent protein expressed in transgenic chloroplasts into the mouse circulatory system. FASEB J 20:959-961

Lössl AG, Waheed MT (2011) Chloroplast-derived vaccines against human diseases: achievements, challenges and scopes. Plant Biotechnol J 9:527-539

Loza-Rubio E, Rojas AE, Gómez L, Olivera FMT, Gómez LM (2008) Development of an edible vaccine in maize using the Vnukovo strain. Dev Biol 131:477-482

Loza-Rubio E, Rojas-Anaya E, López J, Olivera-Flores MT, GómezLim M, Tapia-Pérezd G (2012) Induction of a protective immune response to rabies virus in sheep after oral immunization with transgenic maize. Vaccine 30:5551-5556

Maliga P, Bock R (2011) Plastid biotechnology: food, fuel, and medicine for the 21st century. Plant Physiol 155:1501-1510

Matsui T, Asao H, Ki M, Sawada K, Kato K (2009) Transgenic lettuce producing a candidate protein for vaccine against edema disease. Biosci Biotechnol Biochem 73:1628-1634

Molina A, Hervas-Stubbs S, Daniell H, Mingo-Castel AM, Veramendi J (2004) High-yield expression of a viral peptide animal vaccine in transgenic tobacco chloroplasts. Plant Biotechnol J 2:141-153

Molina A, Veramendi J, Hervás-Stubbs S (2005) Induction of neutralizing antibodies by a tobacco chloroplast-derived vaccine based on a B cell epitope from canine parvovirus. Virology 342:266-275

Munday BL, Kwang J, Moody N (2002) Betanoda virus infections of teleost fish: a review. J Fish Dis 25:127-142

Paul M, van Dolleweerd C, Drake PMW, Reljic R, Thangaraj H, Barbi T, Stylianou E, Pepponi I, Both L, Hehle V, Madeira L, Inchakalody V, Ho S, Guerra T, Ma JKC (2011) Molecular pharming: future targets and aspirations. Hum Vaccin 7(3):375-382

Plant KP, LaPatra SE (2011) Advances in fish vaccine delivery. Dev Comp Immunol 35:1253-1259

Roy S, Tyagi A, Tiwari S, Singh A, Sawant SV, Singh PK, Tuli R (2010) Rabies glycoprotein fused with B subunit of cholera toxin expressed in tobacco plants folds into biologically active pentameric protein. Protein Expr Purif 70(2):184-190. doi: 10.1016/ j.pep.2009.10.002
Ruf S, Hermann M, Berger IJ, Carrer H, Bock R (2001) Stable genetic transformation of tomato plastids and expression of a foreign protein in fruit. Nat Biotech 19:870-875

Ruhlman T, Ahangari R, Devine A, Samsam M, Daniell H (2007) Expression of cholera toxin B-proinsulin fusion protein in lettuce and tobacco chloroplasts - oral administration protects against development of insulitis in non-obese diabetic mice. Plant Biotechnol J 5:495-510

Ruhlman T, Verma D, Samson N, Daniell H (2010) Role of heterologous elements in transgene integration and expression. Plant Physiol 152:2088-2104

Rybicki EP (2010) Plant-made vaccines for humans and animals. Plant Biotechnol J 8:620-637

Sapkota A, Sapkota AR, Kucharski M, Burke J, McKenzie S, Walker P, Lawrence R (2008) Aquaculture practices and potential human health risks: current knowledge and future priorities. Environ Int 34:1215-1226

Smith P (2008) Antimicrobial resistance in aquaculture. In: Bernoth EM (ed) Changing trends in managing aquatic animal disease emergencies. Rev sci tech Off int Epiz 27:243-264

Sommerset I, Skern R, Biering E, Bleie H, Fiksdal IU, Grove S, Nerland AH (2005) Protection against Atlantic halibut nodavirus in turbot is induced by recombinant capsid protein vaccination but not following DNA vaccination. Fish Shellfish Immunol 18:13-29

Streatfield SJ (2007) Approaches to achieve high-level heterologous protein production in plants. Plant Biotechnol J 5:2-15

Van Eck J, Keen P (2009) Continued expression of plant-made vaccines following long-term cryopreservation of antigenexpressing tobacco cell cultures. In Vitro Cell Dev Biol Plant 45:750-757

Vasil IK (2008) A history of plant biotechnology: from the cell theory of Schleiden and Schwann to biotech crops. Plant Cell Rep 27:1432-1440. doi:10.1007/s00299-008-0571-4

Verma D, Moghimi B, LoDuca PA, Singh HD, Hoffman BE, Herzog RW, Daniell H (2010) Oral delivery of bioencapsulated coagulation factor IX prevents inhibitor formation and fatal anaphylaxis in hemophilia B mice. Proc Natl Acad Sci USA 107:7101-7106

Watson J, Koya V, Leppla S, Daniell H (2004) Expression of Bacillus anthracis protective antigen in transgenic chloroplasts of tobacco, a non-food/feed crop. Vaccine 22:4374-4384

Wu Y, Zhao D, Song L, Xu W (2009) Heterologous expression of synthetic chicken IFN-gamma in transgenic tobacco plants. Biologia 64:1115-1122

Yang ZQ, Liu QQ, Pan ZM, Yu HX, Jiao XA (2007) Expression of the fusion glycoprotein of Newcastle disease virus in transgenic rice and its immunogenicity in mice. Vaccine 25:591-598

Yusibov V, Streatfield SJ, Kushnir N (2011) Clinical development of plant-produced recombinant pharmaceuticals: vaccines, antibodies and beyond. Hum Vaccin 7:313-321 